\title{
GAMBARAN KADAR ASAM URAT PADA PENDERITA TUBERKULOSIS PARU YANG MENGKONSUMSI OBAT ANTI TUBERKULOSIS (OAT)
}

\author{
Arie J. Pitono ${ }^{1}$, Ulyati Ulfah ${ }^{2}$, Neng Dini ${ }^{3}$

 \\ ${ }^{2}$ Program Studi Sarjana Farmasi, Fakultas Farmasi, Institut Kesehatan Rajawali, Indonesia \\ ${ }^{3}$ Program Studi DIII Analis Kesehatan, Fakultas Kesehatan, Institut Kesehatan Rajawali, Indonesia
}

\section{INFORMASI ARTIKEL}

Received: November, 22, 2021

Accepted : Februari, 9, 2022

Available online: Februari, 9, 2022

\section{KEYWORDS}

Gout, TB Patients, Anti Tuberculosis Drugs (OAT)

\section{CORRESPONDENCE}

E-mail: ulyatiulfahunpad@ gmail.com

\section{A B S T R A C T}

Background : Tuberculosis (TB) is an infectious disease caused by Mycobacterium tuberculosis. Most TB germs attack the lungs, but can also attack other body organs such as bones and glands. TB treatment is carried out using the DOTS strategy (Directly Observed Treatment Shortcourse) with a treatment time of 6-9 months. The DOTS strategy that uses multi-drug drugs often has side effects on the patient, such as an increase in uric acid levels in the blood.

Research Objectives: The purpose of this study was to determine uric acid levels in patients with pulmonary tuberculosis (TB) who took Anti Tuberculosis Drugs (OAT) based on the length of treatment.

Research Methods: This research method is descriptive by taking secondary data from Lestari Yani Manulu's research at the Special Pulmonary Hospital of Medan City in 2019.

Results: The results of the study of 29 respondents who consumed OAT obtained 17 respondents $(58.62 \%)$ with high uric acid levels with an average uric acid level of $9.33 \mathrm{mg} / \mathrm{dl}$ and 12 respondents (41.38\%) with uric acid levels. normal with an average uric acid level of $4.90 \mathrm{mg} / \mathrm{dl}$. Respondents with high uric acid levels consisted of 12 respondents (100.00\%) with a treatment duration of 1-3 months with an average uric acid level of $6.83 \mathrm{mg} / \mathrm{dl}$, and 5 respondents $(29.41 \%)$ with a duration of treatment of $4-8$ months with an average uric acid level of $8.50 \mathrm{mg} / \mathrm{dl}$.

Conclusion: It was found that high uric acid levels in patients with pulmonary $T B$ who took Anti Tuberculosis Drugs (OAT) were $58.62 \%$ with an average uric acid level of $9.33 \mathrm{mg} / \mathrm{dl}$. High uric acid levels occurred in patients with intensive treatment, namely 1-3 months of $100.00 \%$ with an average uric acid level of $6.83 \mathrm{mg} / \mathrm{dl}$.

\section{PENDAHULUAN}

Tuberkulosis (TB) paru merupakan penyakit yang disebabkan oleh bakteri Mycobacterium tuberculosis. TB adalah penyakit infeksi kronis yang sebagian besar meyerang paru, tetapi dapat juga mengenai organ tubuh lainnya seperti kulit, kelenjar limfe, tulang dan selaput otak (Sudoyo dkk, 2009).
Laporan World Health Organization (WHO) dalam Global Tuberculosis Report 2013 menyatakan bahwa insiden kasus TB diperkirakan 8,6 juta orang dan kasus kematian akibat TB mencapai 1,3 juta pada tahun 2012. Indonesia menempati urutan keempat diantara 22 negara dengan beban TB tertinggi (High Burden Country) di dunia 
yang berjumlah 400-500 ribu kasus insiden TB per 100.000 penduduk pada tahun 2012. Pada tahun 2019 WHO melaporkan Indonesia menduduki posisi ketiga dengan kasus TB tertinggi di dunia. Sementara posisi pertama dan kedua saat ini adalah India dan Tiongkok. Jika melihat data WHO tahun 2-19 menyebutkan jumlah estimasi kasus TB di Indonesia sebanyak 845.000 orang. Jumlah ini meningkat dari sebelumnya sebanyak 843.000 orang. Ini menepatkan Indonesia sebagai salah satu negara penyumbang $60 \%$ dari seluruh kasus TB di dunia.

Menurut kementerian kesehatan RI pada Tahun 2011, Provinsi Jawa Timur memiliki kasus TB terbanyak kedua setelah Provinsi Jawa Barat. Data Dinas Kesehatan Provinsi Jawa Timur tahun 2011 menunjukkan kasus TB mencapai 41.404 kasus, sementara Jawa Barat mencapai 62.563 kasus. Kota Surabaya memiliki kasus TB terbanyak di Provinsi Jawa Timur yaitu 3990 kasus, diikuti Kabupaten Jember dengan 3334 kasus. Kematian TB di Kota Surabaya diperkirakan mencapai 10.108 penderita BTA positif .

Menurut kementerian kesehatan Republik Indonesia Tahun 2013, penyakit TB merupakan penyebab kematian nomor tiga setelah penyakit kardiovaskular dan penyakit saluran napas pada semua kelompok usia, dan nomor satu dari golongan penyakit infeksi. Hasil Riset Kesehatan Dasar bulan Mei-Juni 2013 melaporkan bahwa prevalensi nasional TB paru tidak berbeda dengan tahun 2007 yaitu 0,4\% dari seluruh penyakit di Indonesia.

Menurut kementerian kesehatan Republik Indonesia Tahun 2011, upaya pengendalian TB secara nasional dilakukan dengan menerapkan strategi DOTS (Directly Observed Treatment Shortcourse) mulai tahun 1995, yaitu strategi penatalaksanaan TB yang menekankan pentingnya pengawasan untuk memastikan pasien menyelesaikan pengobatan sesuai ketentuan sampai dinyatakan sembuh. Strategi DOTS (Directly Observed Treatment Shortcourse) terdiri dari 5 komponen kunci, yaitu; 1) komitmen politis yang berkesinambungan; 2) penemuan kasus melalui pemeriksaan dahak mikroskopis yang terjamin mutunya; 3) pengobatan yang standar, dengan supervisi dan dukungan bagi pasien; 4) keteraturan penyediaan obat yang dijamin kualitasnya; dan 5) sistem pencatatan dan pelaporan yang mampu memberikan penilaian terhadap hasil pengobatan pasien dan kinerja keseluruhan program (Kemenkes Republik Indonesia, 2013). Pengobatan strategi DOTS ini umumnya diberikan hingga 6-8 bulan yang diawasi oleh seorang Pengawas Menelan Obat (PMO) untuk menjamin kepatuhan pasien dalam mengkonsumsi obat. Pengobatan diberikan dalam bentuk kombinasi obat dengan jumlah yang tepat dan teratur, agar semua bakteri dapat dipastikan mati. Obat Anti Tuberkulosis (OAT) yang digunakan antara lain isoniazid $(\mathrm{H})$, streptomisin $(\mathrm{S})$, etambutol $(\mathrm{E})$, rifampisin $(\mathrm{R})$, dan pirazinamid $(\mathrm{P})$.

Pengobatan TB yang menggunakan prinsip multidrug dengan jangka waktu yang lama ser ing menimbulkan efek samping salah satunya adalah peningkatan kadar asam urat $(\geq 7 \mathrm{mg} / \mathrm{dL})$ dalam tubuh. Asam urat merupakan bagian yang normal dari darah dan urin. Asam urat dihasilkan dari pemecahan nukleotida purin yang berasal dari makanan maupun dari nukleotida purin yang diproduksi oleh tubuh. Mekanisme yang menyebabkan terjadinya kelebihan asam urat dalam darah yaitu karena produksinya yang berlebih atau penurunan sekresi asam urat melalui urin (Nafilla dkk, 2017 ; Yenrina \& Krisnatuti, 2008).

Obat Antituberkulosis (OAT) yang digunakan seperti pirazinamid dan etambutol akan menghambat pertukaran ion asam urat pada tubulus ginjal sehingga asam urat yang seharusnya dikeluarkan namun menjadi terreabsorbsi kembali kedalam darah. Hal ini sesuai dengan laporan kasus oleh Halimatu Sahdiah Siahan di Universitas Lampung yang menunjukkan adanya peningkatan terhadap kadar asam urat dalam darah pada pasien yang menerima terapi OAT. Berdasarkan penelitian oleh Irwanto Kondo dkk menunjukkan peningkatan kadar asam urat yang signifikan jika mengkonsumsi kombinasi OAT pirazinamid dan etambutol secara bersamaan (Siahaan, 2014 ; Kondo dkk, 2016).

\section{METODE}

Jenis penelitian yang digunakan pada penelitian ini adalah penelitian deskriptif dengan menggunakan data sekunder dari hasil penelitian Lestari Yani Manalu di Rumah Sakit Khusus Paru Kota Medan pada tahun 2019. 
Variabel pada penelitian ini adalah kadar asam urat penderita tuberkulosis paru yang mengkonsumsi Obat Anti Tuberkulosis (OAT) di Rumah Sakit Khusus Paru Kota Medan. Populasi pada penelitian ini adalah 29 pasien yang telah positif terdiagnosia TB paru yang sedang mengkonsumsi Obat Anti Tuberkulosis (OAT) di Rumah Sakit Khusus Paru Kota Medan. Sampel pada penelitian ini adalah semua populasi penelitian. Teknik pengambilan sampel dalam penelitian ini adalah non probability sampling yaitu quota sampling.
Teknik pengumpulan data pada penelitian ini dilakukan dengan cara mengambil data sekunder dari penelitian Lestari Yani Manalu pada tahun 2019. Data yang telah terkumpul akan diolah dan dianalisis dengan analisis deskriptif untuk menggambarkan kadar asam urat pada penderita Tuberkulosis (TB) paru yang sedang mengkonsumsi Obat Anti Tuberkulosis (OAT) di Rumah Sakit Khusus Paru Kota Medan pada tahun 2019.

\section{HASIL DAN DISKUSI}

\section{Tabel}

\section{Distribusi Berdasarkan Kadar Asam Urat}

\begin{tabular}{cccc}
\hline \multirow{2}{*}{ Kadar asam urat } & Tinggi & Normal & Jumlah \\
\cline { 2 - 4 } & $17(58,62 \%)$ & $12(41,38 \%)$ & \multirow{2}{*}{$29(100,00 \%)$} \\
Rata-rata & $9,33 \mathrm{mg} / \mathrm{dl}$ & $4,90 \mathrm{mg} / \mathrm{dl}$ & \\
\hline
\end{tabular}

Berdasarkan tabel 1. dari 29 responden yang mengkonsumsi OAT didapatkan 17 responden (58,62\%) dengan kadar asam urat tinggi dengan rata-rata kadar asam urat 9,33 mg/dl dan 12 responden $(41,38 \%)$ dengan kadar asam urat normal dengan rata-rata kadar asam urat 4,90 $\mathrm{mg} / \mathrm{dl}$.

\section{Distribusi Berdasarkan Lama Pengobatan}

\begin{tabular}{ccccc}
\hline & & & Kadar asam urat & \\
& & Tinggi & Normal & Jumlah \\
\hline Lama & $1-3$ bulan & $12(100,00 \%)$ & $0(0,00 \%)$ & $12(100,00 \%)$ \\
pengobatan & $4-8$ bulan & $5(29,41 \%)$ & $12(70,59 \%)$ & $17(100,00 \%)$ \\
& & $17(58,62 \%)$ & $12(41,38 \%)$ & $29(100,00 \%)$ \\
\end{tabular}

Berdasarkan Tabel 2. terdapat 17 responden dengan kadar asam urat tinggi terdiri dari 12 responden (100,00\%) dengan lama pengobatan 1-3 bulan, 5 responden (29,41\%) dengan lama pengobatan 4-8 bulan. 12 responden dengan kadar asam urat normal terdiri dari 12 responden (70,59\%) dengan lama pengobatan 4-8 bulan.

\section{Rata-rata Kadar Asam Urat Berdasarkan Lama Pengobatan}

\begin{tabular}{ccccc}
\hline & \multicolumn{2}{c}{ Kadar asam urat } \\
Lama \\
\cline { 2 - 5 } pengobatan & $1-3$ bulan & $4-8$ bulan & $1-3$ bulan & $4-8$ bulan \\
Rata-rata & $6,83 \mathrm{mg} / \mathrm{dl}$ & $8,50 \mathrm{mg} / \mathrm{dl}$ & 0 & $4,90 \mathrm{mg} / \mathrm{dl}$ \\
\hline
\end{tabular}


Berdaskan tabel 3. kadar asam urat tinggi untuk lama pengobatan 1- 3 rata-rata kadar asam uratnya adalah 6,83 mg/dl dan untuk lama pengobatan 4-8 bulan rata-rata kadar asam uratnya adalah 8,50 mg/dl. Kadar asam urat normal untuk lama pengobatan 4-8 bulan kadar asam uratnya adalah 4,90 mg/dl.

\section{PEMBAHASAN}

Hasil dari data penelitian yang dilakukan oleh Lestari Yani Manalu untuk mengetahui gambaran kadar asam urat pada penderita tuberkulosis paru yang mengkonsumsi Obat Anti Tuberkulosis (OAT) pada 29 responden yang mengkonsumsi OAT didapatkan 17 responden $(58,62 \%)$ dengan kadar asam urat tinggi dengan kadar asam urat rata-rata 9,33 $\mathrm{mg} / \mathrm{dl}$ dan 12 responden $(41,38 \%)$ dengan kadar asam urat normal dengan kadar asam urat rata-rata 4,90 $\mathrm{mg} / \mathrm{dl}$. Hal ini sesuai dengan laporan kasus oleh Halimatu Sahdiah Siahan di universitas lampung yang menyatakan adanya peningkatan kadar asam urat dalam darah hingga angka 12,10 mg/dl (Siahaan, 2014). Berdasarkan penelitian sebelumnya oleh Irwanto Kondo dkk yang berjudul gambaran kadar asam urat pada penderita tuberkulosis paru yang menerima terapi obat anti tuberkulosis Di RSUP Prof. Dr. R. D. Kandou Manado periode Juli 2014 - Juni 2015 menunjukkan adanya peningkatan kadar asam urat sebesar $60 \%$ (Kondo dkk, 2016).

Pada hasil penelitian Nafilla dkk yang berjudul kadar asam urat pada pasien tuberkulosis dengan terapi Obat Anti Tuberkulosis (OAT) Di Puskesmas Cempaka Maret 2017 menunjukkan sebanyak 75\% laki-laki yang mengkonsumsi OAT mengalami peningkatan kadar asam urat dengan kadar asam urat rata-rata 9,16 mg/dl.

Sedangkan pada perempuan sebanyak $25 \%$ dengan kadar asam urat rata-rata 12,1 mg/dl. (Nafilla dkk, 2017). Kebanyakan laki-laki memiliki tingkat asam urat serum lebih tinggi daripada wanita, karena laki-laki tidak memiliki hormon estrogen, dimana fungsi hormon estrogen adalah membantu pembuangan asam urat ke urin (Widyanto, 2014).

Berdasarkan hasil penelitian Irwanto Kondo dkk yang berjudul gambaran kadar asam urat pada penderita TB yang menerima terapi Obat Anti Tuberkulosis (OAT) di RSUP Prof. Dr. R. D Kandou Manado peiode Juli 2014-
Juni 2015 menunjukkan sebesar 46,67\% peningkatan kadar asam urat terjadi pada kelompok umur 46-65 tahun (Kondo dkk, 2016). Hal ini terjadi karena setelah umur 30 tahun kemampuan ginjal akan mulai menurun dan pada usia 60 tahun kemampuan ginjal hanya 50\%, hal ini disebabkan oleh penurunan fungsi nefron dan tidak adanya kemampuan regenerasi sel (Kondo dkk, 2016).

Berdasarkan lama pengobatan, terdapat 17 responden dengan kadar asam urat tinggi terdiri dari 12 responden $(100,00 \%)$ dengan lama pengobatan 1-3 bulan dengan kadar asam urat rata-rata $6,83 \mathrm{mg} / \mathrm{dl}, 5$ responden $(29,41 \%)$ dengan lama pengobatan 4-8 bulan dengan kadar asam urat rata-rata 8,50 mg/dl. 12 responden dengan kadar asam urat normal terdiri dari 12 responden $(70,59 \%)$ dengan lama pengobatan 4-8 bulan dengan kadar asam urat rata-rata 4,90 mg/dl. Hal ini sesuai dengan penelitian yang di lakukan oleh Irwanto Kondo dkk pada tahun 2016 yang menunjukan sebanyak $80 \%$ peningkatan kadar asam urat terjadi pada penderita TB dengan pengobatan tahap intensif (1-3 bulan) dan sebanyak $20 \%$ terjadi pada pengobatan tahap lanjut. Hal ini dikarenakan pada pengobatan TB metode DOTS dikelompokkan menjadi 2 tahap yaitu tahap intensif (awal) dan tahap lanjut (Kemenkes, 2011). Tahap intensif (awal) dilakukan dengan tujuan untuk membunuh kuman Mycobacterium tuberculosis, tahap ini menggunakan dosis obat $2 \mathrm{x}$ lebih banyak dari tahap lanjut dimana pasien harus mengkonsumsi 4 jenis obat yaitu isoniazid, rifampisin, pirazinamid, dan etambutol. Sementara tahap lanjut dilakukan dengan tujuan untuk memastikkan bakteri tersebut benar-benar mati, dimana pada tahap ini menggunakan dosis yang lebih sedikit biasanya hanya 2 jenis obat yang dikonsumsi yaitu isoniazid dan rimfapisin (Depkes RI, 2005). Teknik pengobatan multi drug dengan mengkonsumsi obat secara kombinasi yaitu isoniazid $(\mathrm{H})$, rifampisin $(\mathrm{R})$, pirazinamid (Z) dan etambutol (E) dengan waktu yang lama akan 
menimbulkan efek samping. Obat Anti Tuberculosis (OAT) terutama pirazinamid dan etambutol akan menghambat pertukaran ion asam urat pada tubulus ginjal sehingga asam urat yang seharusnya dikeluarkan namun menjadi

\section{SIMPULAN}

1. Ditemukan kadar asam urat tinggi pada pasien penderita TB paru yang mengkonsumsi Obat Anti Tuberkulosis (OAT) sebesar 58,62\% dengan kadar asam urat rata-rata $9,33 \mathrm{mg} / \mathrm{dl}$.

\section{REFERENSI}

${ }^{[1]}$ Akhzami DR, Rizki M, Setyorini RH. Perbandingan hasil point of care testing (POCT) asam urat dengan chemistry analyzer. Jurnal Kedokteran 2016;5(4)15-19.

${ }^{[2]}$ Dianati NA. Gout and hyperuricemia. J Majority 2015;4(3) 82-9.

${ }^{[3]}$ Departemen Kesehatan Republik Indonesia. Pharmaceutical care untuk tuberkulosis. Jakarta: Departemen Kesehatan; 2005.

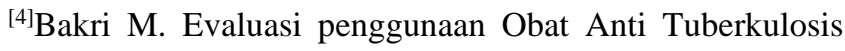
(OAT) pada pasien tuberkulosis paru di Puskesmas Jumpandang Baru Makassar. [Skripsi] Makassar: Fakultas Kedokteran dan Ilmu kesehatan Universitas Islam Negeri Alauddin Makassar: 2016.

${ }^{[5]}$ Kementerian Kesehatan Republik Indonesia. Profil kesehatan Indonesia 2012. Jakarta: Kementerian Kesehatan Republik Indonesia; 2013.

${ }^{[6]}$ Kementerian Kesehatan Republik Indonesia. Pedoman nasional pengendalian tuberkulosis. Jakarta: Kementerian Kesehatan; 2011.

${ }^{[7]}$ Kementerian Kesehatan Republik Indonesia. Tuberkulosis. Jakarta: Pusat Data dan Informasi Kementrian Republik Indonesia; 2018.

${ }^{[8]}$ Kondo I, Wongkar MCP, Ongkowijaya J. Gambaran kadar asam urat pada penderita tuberkulosis paru yang menerima terapi obat anti tuberkulosis di RSUP Prof. DrR. terreabsorbsi kembali kedalam darah. Pengkombinasian OAT pirazinamid dan etambutol ini dapat meningkatkan reabsorbsi asam urat hingga $2 \mathrm{x}$ lipat (Kondo dkk, 2016).

2. Kadar asam urat tinggi terjadi pada pasien dengan pengobatan tahap intensif yaitu 1-3 bulan sebesar $100,00 \%$ dengan kadar asam urat $6,83 \mathrm{mg} / \mathrm{dl}$.

D. Kandou Manado periode juli 2014 juni 2015. Jurnal e-Clinic (eCl) 2016; 4(1): $344-8$.

${ }^{[9]}$ Manalu LY. Gambaran kadar asam urat pada penderita tuberkulosis paru yang mengkonsumsi Obat Anti Tuberkulosis (OAT) di Rumah Sakit Khusus Paru Kota Medan. [KTI]. Medan: Politeknik Kesehatan Kemenkes RI Medan: 2019.

${ }^{[10]}$ Masriadi. Epidemiologi penyaklit menular. Depok: PT. Rajagrafindo Persada; 2017.

${ }^{[11] N a f i l l a, ~ H a q i q i ~ R N, ~ W a h y u n i t a ~ S . ~ G a m b a r a n ~ k a d a r ~ a s a m ~}$ urat pada pasien tuberkulosis dengan terapi Obat Anti Tuberkulosis (OAT) di Puskesmas Cempaka Maret 2017. Jurnal ERGASTERIO 2017;05(01)173-

${ }^{[12]}$ Nursalam. Konsep dan penerapan metodologi penelitian ilmu keperawatan. Jakarta: Salemba Medika; 2008.

${ }^{[13]}$ Siahaan HS. A 54 years old male patient with tuberculosis and arthritis gout. Jurnal Medula Unila 2014;3(1):37-45.

${ }^{[14]}$ Sudoyo AW, Setiyohadi B, Alwi I, Simadibrata M, Setiati S. Buku ajar ilmu penyakit dalam. 5th ed. Jakarta: Iterna Publishing Pusat Penerbitan Ilmu Penyakit Dalam; 2009.

${ }^{[15]}$ Utami P, Lentera T. Tanaman obat untuk mengatasi rematik \& asam urat. Jakarta: PT. Agro Media Pustaka; 2003. 
${ }^{[16]}$ Yenrina R, Krisnatuti D. Diet sehat untuk penderita asam urat. Jakarta: Penebar Swadya; 2008.

${ }^{[17]}$ Widyanto, FW. Artritis Gout dan Perkembangannya. 2014;10(2):145-152.

${ }^{[18]}$ World Health Organization. Global tuberculosis report 2012. WHO Library Cataloguing-inPublication Data. [Online]. 2012 [Cited 2020 Maret 22]; Available from:URL: https://apps.who.int/iris/handle/10665/75 $\underline{938}$

${ }^{[19]}$ World Health Organization. Global tuberculosis report 2013. WHO Library Cataloguing-inPublication Data, [Online]. 2013 [Cited 2020 Maret 26]; Available from:URL: https://apps.who.int/iris/handle/10665/75 $\underline{938}$ 